\title{
The risk of job burnout among medical workers on the basis of their work-related behaviors
}

\author{
BOŻENA MROCZEK ${ }^{1, A-G}$, WERONIKA WOLIŃSKA ${ }^{1, B, F}$, ARTUR KOTWAS $^{2, c, ~}$, \\ IWONA KARPETA-PAWLAK ${ }^{1, B, F}$, DONATA KURPAS ${ }^{3,4, C-E}$ \\ ${ }^{1}$ Department of Human Sciences in Medicine of the Pomeranian Medical University in Szczecin, Poland \\ ${ }^{2}$ Chair and Department of Public Health of the Pomeranian Medical University in Szczecin, Poland \\ ${ }^{3}$ Chair and Department of Family Medicine of the Wroclaw Medical University, Poland \\ ${ }^{4}$ Opole Medical School, Poland
}

A - Study Design, B - Data Collection, C - Statistical Analysis, D - Data Interpretation, E - Manuscript Preparation, F - Literature Search, G - Funds Collection

\begin{abstract}
Summary Background. Burnout syndrome is closely related to career-related issues.
Objectives. The purpose of this study was to determine work-related behaviors presented by physicians, nurses and paramedics with regard to their sociodemographic data and social competence.

Material and methods. The study was conducted in 2015-2016 and involved 432 medical workers, including 144 (33.5\%) physicians, 165 (37.7\%) nurses and 123 (28.8\%) paramedics. The median age was 28 years (range: 20-66). The research instruments were: the Work-Related Behavior and Experience Pattern (AVEM) questionnaire, the Social Competence Questionnaire (SCQ) by Anna Matczak and a self-developed questionnaire.

Results. Symptoms of burnout syndrome (Type B) were observed in one-fourth of medical workers. 31.8\% (135) of all participants presented Type $\mathrm{G}$. The behavior types prevailing in particular groups were as follows: paramedics - Type $\mathrm{G}$ and Type S; physicians - Risk Type A and Type B, nurses - Type B and Type G. 62.4\% (189) of the participants had an average level of general competence (4-7 sten), and $15.8 \%(48)$ had a low level of general competence (1-3 sten). The general competence level correlated with Type G $(r=0.17 ; p=0.05)$. Conclusions. Burnout syndrome (Type B) occurs in physicians, nurses and paramedics regardless of their place of work and is related to a low level of social competence. A high level of social competence protects physicians, nurses and paramedics against job burnout. Key words: burnout professional, social skills, physicians, nurses, emergency medical technicians, AVEM.
\end{abstract}

Mroczek B, Wolińska W, Kotwas A, Karpeta-Pawlak I, Kurpas D. The risk of job burnout among medical workers on the basis of their work-related behaviors. Fam Med Prim Care Rev 2018; 20(1): 29-35, doi: https://doi.org/10.5114/fmpcr.2018.73701.

\section{Background}

Burnout syndrome is closely related to career-related issues [1]. In medical professionals, it is the result of their type of work, where emotional involvement is the basis of cooperation with patients $[1,2]$. Freudenberger described job burnout as a loss of motivation and physical energy to work. They also defined it as a worker's withdrawal syndrome, resulting from an overload of tasks posed by the social and physical working environment, as well as self-appointed tasks [3]. Kalimo et al., on the other hand, indicated that burnout is a consequence of exposure to prolonged work-related stress, which mainly refers to professions that involve personal contact with other people, the necessity of making quick, responsible decisions and emotional commitment [4]. This group includes medical workers, especially physicians, nurses and paramedics [2,5-8].

Burnout syndrome, which is characterized by high dynamism, has negative - both personal and institutional - consequences for the healthcare system $[6,9,10]$. In the International Classification of Diseases (ICD-10), burnout syndrome is coded as ICD-10 273.0. Unlike other occupational diseases, it does not entail dysfunction of specific organs, but is rather a psychosocial state. Sapilak et al. recommend that when diagnosing burnout syndrome, we should distinguish it from physical fatigue and depression [5]. Negative work-related consequences have direct effects on workers' health (mental disorders) and indirectly contribute to the quality of healthcare, as well as legal and economic problems [7, 11-16]. In individual cases, job burnout manifests itself in psychosomatic problems, such as insomnia, headaches, back pain and cardiovascular disorders [17], as well as emotional problems, including anger, depression, hostility, aggression, apathy, distrust of co-workers and isolation [7], possibly leading to alcoholism [18]. Therefore, the burnout process among medical professionals is the result of the confrontation of working environment conditions with the individual personality traits of workers $[19,20]$. Study results of other authors show that factors differentiating the level of burnout include working conditions related to the medical profession, not the profession itself $[1,21,22]$.

So far, no complex rules have been developed that indicate a person is suffering from burnout syndrome or is not showing any symptoms yet. However, it is still possible to evaluate the degree of symptoms intensity on a scale from perfect well-being to complete burnout [23]. Many researchers indicate that some sociodemographic data, work-related issues and the level of social competence play an important part in burnout syndrome $[12,24,25]$, as they can both contribute to and prevent this problem [12, 18, 26-29]. When performing their professional duties, physicians, nurses and paramedics face difficult, stressful situations, with which they have to deal immediately. They often get emotionally involved, and face the need to engage in solving other people's problems. Kapała proves that in the medical professional - patient relationship, the crucial aspect is the degree of involvement of medical professionals in solving the health problems of their patients [30]. 
According to Schaarschmidt and Fischer and Schaarschmidt and other scholars, when diagnosing burnout syndrome, we should take into account such aspects as the interaction between employees and their work environment, their attitudes to job requirements and their views on various situations and experiences at work $[1,16,21,31]$.

We sought an answer to the question concerning the relationship between work-related behaviors and selected factors in a group of physicians, nurses and paramedics.

\section{Objectives}

The purpose of this study was to analyze the types of work-related behaviors in a group of physicians, nurses and paramedics with regard to sociodemographic factors and the level of social competence.

The following hypotheses were formulated:

1. Medical workers present similar types of work-related behaviors irrespective of workplace context.

2. There are differences in job burnout levels between physicians, nurses and paramedics, depending on age, sex, education, years in the profession and years in the present job.

3. Medical workers with high social competence are characterized by a low level of burnout syndrome.

\section{Material and methods}

The study was conducted in 2015-2016 with the consent of the Bioethical Commission of the Pomeranian Medical University in Szczecin, Poland (KB-0012/92/12/2014).

\section{Material}

The criteria of inclusion in the study were the workplace and current profession. Those invited to the study were physicians and nurses from internal diseases, surgical and pediatric wards in Szczecin, paramedics providing emergency service in Szczecin and primary care physicians in Szczecin and Wroclaw. The study involved 432 medical workers from two medical centers (Szczecin and Wroclaw) composed of 144 (33.5\%) physicians, 165 (37.7\%) nurses and 123 (28.8\%) paramedics. The average age of the medical workers was $33.6 \pm 11.6$ years. Detailed sociodemographic data is presented in Table 1.

\section{Methods}

Two research instruments were employed in the study: a standardized questionnaire, the Work-Related Behavior and Experience Patterns (AVEM) [1, 21, 27] and the Social Competence Questionnaire (SCQ) [32].

The AVEM questionnaire measures an individual's resources in the context of handling job requirements, types of behavior determining mental health, risk of developing mental health problems, potential threats and types of psychological interventions $[21,27]$. It consists of 66 statements divided into 11 scales (each including 6 statements) and is scored on a five-point Likert scale (from 'I totally agree' to 'I totally disagree'). The scales of the questionnaire measure three dimensions of work-related behavior and experiences that influence one's effectiveness at work $[1,21,27]$ :

1. Commitment to work expressed in terms of perceived significance of work, career ambition, tendency to exert, striving for perfection, the ability to keep an emotional distance between work and private life.

2. Resistance to stress is regarded in terms of one's tendency to resign in the case of failure, active coping with problems, as well as balance and emotional stability.

3. Emotional or subjective well-being is described in terms of perceived social support, satisfaction with life and satisfaction with work.

The above elements determine individual ways of handling job requirements and make up a specific psychological factor that protects a worker's mental health.

\begin{tabular}{|c|c|c|c|c|c|c|}
\hline \multicolumn{2}{|l|}{ Variable } & \multirow{2}{*}{$\begin{array}{l}\text { Total } \\
n(\%) \\
432(100)\end{array}$} & \multirow{2}{*}{ 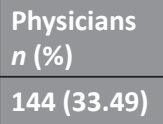 } & \multirow{2}{*}{$\begin{array}{l}\begin{array}{l}\text { Nurses } \\
n(\%)\end{array} \\
165(37.73)\end{array}$} & \multirow{2}{*}{$\begin{array}{l}\text { Paramedics } \\
n(\%) \\
123(28.77) \\
\end{array}$} & \multirow{2}{*}{$\begin{array}{l}{ }^{*} \mathrm{H} / \\
{ }^{* *} \mathrm{chi}^{2} \\
p\end{array}$} \\
\hline & & & & & & \\
\hline Sex & $\begin{array}{l}\text { female } \\
\text { male }\end{array}$ & $\begin{array}{l}296(100) \\
136(100)\end{array}$ & $\begin{array}{l}101(34.1) \\
43(31.6)\end{array}$ & $\begin{array}{l}159(53.7) \\
6(4.4)\end{array}$ & $\begin{array}{l}36(12.2) \\
87(64)\end{array}$ & $\begin{array}{l}* * 147.33 \\
<0.001\end{array}$ \\
\hline Age & $\begin{array}{l}\mathrm{X} \pm \mathrm{SD} \\
\mathrm{Me} \\
\min --\max . \\
\mathrm{Q}_{1}-\mathrm{Q}_{3} \\
\end{array}$ & $\begin{array}{l}33.6 \pm 11.7 \\
28 \\
21-66 \\
24-42 \\
\end{array}$ & \begin{tabular}{|l}
$32.8 \pm 11.6$ \\
28 \\
$23-66$ \\
$25-39$ \\
\end{tabular} & \begin{tabular}{|l}
$36.9 \pm 12.6$ \\
39 \\
$21-61$ \\
$23-48$ \\
\end{tabular} & $\begin{array}{l}29.9 \pm 9.3 \\
26 \\
20-56 \\
23-35 \\
\end{array}$ & $\begin{array}{l}* 17.12 \\
<0.001\end{array}$ \\
\hline $\begin{array}{l}\text { Place of residence } \\
\text { (population) }\end{array}$ & $\begin{array}{l}\text { town }(<5,000) \\
\text { city }(5,000-500,000) \\
\text { city }(>500,000)\end{array}$ & $\begin{array}{l}72(100) \\
142(100) \\
218(100)\end{array}$ & $\begin{array}{l}20(28.2) \\
38(26.8) \\
86(39.4)\end{array}$ & $\begin{array}{l}25(35.2) \\
47(33.1) \\
93(42.7)\end{array}$ & $\begin{array}{l}27(37.5) \\
57(40.1) \\
39(17.9)\end{array}$ & $\begin{array}{l}* * 24.22 \\
<0.001\end{array}$ \\
\hline Education & \begin{tabular}{|l} 
secondary \\
bachelor's degree \\
master's degree \\
\end{tabular} & $\begin{array}{l}97(100) \\
150(100) \\
185(100) \\
\end{array}$ & \begin{tabular}{|l|}
$0(0)$ \\
$0(0)$ \\
$144(77.8)$ \\
\end{tabular} & $\begin{array}{l}53(54.6) \\
86(57.3) \\
26(14.1) \\
\end{array}$ & $\begin{array}{l}44(45.4) \\
64(42.7) \\
15(8.1) \\
\end{array}$ & $\begin{array}{l}* 237.43 \\
<0.001\end{array}$ \\
\hline $\begin{array}{l}\text { Years in the profes- } \\
\text { sion }\end{array}$ & $\begin{array}{l}\mathrm{X} \pm \mathrm{SD} \\
\mathrm{Me} \\
\min .-\max . \\
\mathrm{Q}_{1}-\mathrm{Q}_{3} \\
\end{array}$ & $\begin{array}{l}14.9 \pm 12.2 \\
12 \\
0-40 \\
3-24.5 \\
\end{array}$ & \begin{tabular}{|l}
$10.9 \pm 12.7$ \\
4 \\
$0-40$ \\
$2-19$ \\
\end{tabular} & \begin{tabular}{|l}
$21.3 \pm 10.4$ \\
21.5 \\
$1-42$ \\
$17-28.75$ \\
\end{tabular} & $\begin{array}{l}10.6 \pm 10.4 \\
8 \\
1-37 \\
2-15.75 \\
\end{array}$ & $\begin{array}{l}* 51.27 \\
<0.001\end{array}$ \\
\hline $\begin{array}{l}\text { Years in the previous } \\
\text { job }\end{array}$ & $\begin{array}{l}\mathrm{X} \pm \mathrm{SD} \\
\mathrm{Me} \\
\min --\max . \\
\mathrm{Q}_{1}-\mathrm{Q}_{3} \\
\end{array}$ & $\begin{array}{l}11.27 \pm 11.2 \\
7 \\
0-42 \\
2-18.5 \\
\end{array}$ & \begin{tabular}{|l}
$7.3 \pm 10.0$ \\
3 \\
$0-39$ \\
$1-10$ \\
\end{tabular} & \begin{tabular}{|l}
$15.9 \pm 11.3$ \\
15 \\
$1-42$ \\
$5.25-24$ \\
\end{tabular} & $\begin{array}{l}9.10 \pm 10.1 \\
5.5 \\
1-37 \\
1.25-11.75 \\
\end{array}$ & $\begin{array}{l}* 42.92 \\
<0.001\end{array}$ \\
\hline Workplace & $\begin{array}{l}\text { primary care center hospital } \\
\text { emergency department } \\
\text { other healthcare } \\
\text { institutions }\end{array}$ & $\begin{array}{l}30(100) \\
168(100) \\
79(100) \\
155(100)\end{array}$ & $\begin{array}{l}25(83.3) \\
50(29.8) \\
7(8.9) \\
62(40.0)\end{array}$ & $\begin{array}{l}5(16.7) \\
96(57.1) \\
3(3.8) \\
61(39.4)\end{array}$ & $\begin{array}{l}0(0) \\
22(13.1) \\
69(87.3) \\
32(20.6)\end{array}$ & $\begin{array}{l}* 205.35 \\
<0.001\end{array}$ \\
\hline
\end{tabular}

${ }^{*} \mathrm{H}-$ Kruskal-Wallis test value; ${ }^{* *} \mathrm{chi}^{2}-$ Pearson's test of independence; $p$ - level of significance. 
The respondents' responses to the AVEM questionnaire were organized and entered into the UPS computer system (license no. PRV/010612/EDU), which is an integral part of the questionnaire and serves for computing data. Responses to specific questions were introduced according to the key, and the respondents were assigned to one of four types of behaviors. The following terms were used to describe these behavior types $[6,21]$ :

Type $\mathrm{G}$ - healthy behaviors,

Type $S$ - unambitious,

Risk Type A - symptoms of excessive ambition,

Type B - symptoms of burnout syndrome.

The level of social competence was measured using the Social Competence Questionnaire (SCQ), developed by Matczak [32]. This is a self-report instrument consisting of 90 items, including 60 diagnostic items (concerning social competence) and 30 non-diagnostic items (concerning other abilities). The sum of the scores for the diagnostic items is the total score. The diagnostic items were developed on the basis of the classification of difficult social situations proposed by Argyle [33]. Based on the results of factor analysis, three social scales were included in the final version of the questionnaire:

The (I) scale, which refers to competence determining the effectiveness of behaviors in situations of close interpersonal contact with patients, listening to patients, showing understanding and empathy for their fears and tolerance for their impatience and dissatisfaction with therapeutic effects. This scale contains 15 items; the minimum score is 15 points, and the maximum is 60 points.

The (SE) scale, which refers to being an object of attention and potential appraisal from many people, includes 18 items and has a minimum score of 18 points and a maximum of 72 points.

The (A) scale, which refers to attaining one's own goals and satisfying needs through persuasion and the ability to influence others and resist the influence of others, includes 17 items and has a minimum score of 17 points and a maximum score of 68 points.

The point scores were converted into sten scores: 1-3 sten was considered a low score, 4-7 sten was considered an average score, and 8-10 was considered a high score [32].

\section{Statistical analyses}

The type of distribution was determined for all variables. The Shapiro-Wilk test was employed to verify the normality of these distributions, and all variables had non-normal distributions $(0.875 ; p<0.001)$. Arithmetic means, standard deviations, medians and ranges of variability (extremes) were calculated for the measurable (quantitative) variables, while frequencies (percentages) were determined for qualitative variables. Logistic regression was used to determine the influence of explanatory variables on the odds ratio (OR) of having higher social competence with a $95 \%$ confidence interval. The level of significance for all tests was set at alfa $=0.05$. Statistical analyses were performed using SPSS v. 18 software.

\section{Results}

Symptoms of burnout syndrome (Type B) and symptoms of excessive ambition (Risk Type A) were noted in one-fourth of the respondents. Physicians suffer mainly from burnout syndrome (B) and risk type (A), whereas nurses - burnout syndrome (B) and healthy-ambitious type (G). Paramedics are a group with a healthy-ambitious type (G) and an unambitious type (S) of work-related behaviors (Table 2).

Factors which contributed to differences in the types of work-related behaviors and experiences between the professional groups were: age, years in the profession and years in the present job (Table 3), as well as the female gender in the group of paramedics (chi $\left.{ }^{2}=13.44 ; p=0.004\right)$, third-level education in the group of nurses $\left(\mathrm{chi}^{2}=15.60 ; p=0.02\right)$ and work in hospital settings in the group of paramedics $\left(\mathrm{chi}^{2}=9.34 ; p=0.02\right)$. Females were less likely to exhibit Type $\mathrm{S}$ behavior (unambitious) $(15.2 \%)$ than men $(\mathrm{OR}=0.85,95 \% \mathrm{Cl} 0.71-1.01) ; p=0.07$.

The majority of healthcare workers $(62.7 \%, 271)$ had average general social competence (4-7 sten), and $15.3 \%$ (66) had low competence (1-3 sten) (Table 4). High levels of general social competence and of I, A, and SE competence were observed in every sixth medical worker. There were significant differences between physicians, nurses and paramedics. The level of competence in intimate situations (I) - which involve listening to patients confiding their personal problems - differs nurses $(6.84 \pm 2.67)$ from physicians $(5.62 \pm 2.37)$ and paramedics $(5.81$ $\pm 2.19)-\mathrm{F}=11.09 ; p<0.001$. Competence in situations demanding assertiveness $(A)-$ i.e. exerting influence on and resisting the influence of other people - differentiates nurses

\begin{tabular}{|l|l|l|l|l|}
\hline \multicolumn{6}{|l|}{ Table 2. Distribution of work-related behavior types in the groups of physicians, nurses and paramedics } \\
\hline $\begin{array}{l}\text { Types of work-related behavior and } \\
\text { experiences according to the AVEM }\end{array}$ & $\begin{array}{l}\text { Physicians } \\
n(\%)\end{array}$ & $\begin{array}{l}\text { Nurses } \\
n(\%)\end{array}$ & $\begin{array}{l}\text { Paramedics } \\
n(\%)\end{array}$ & $\begin{array}{l}\text { Total } \\
n(\%)\end{array}$ \\
\hline Type G (healthy-ambitious) & $34(23.9)$ & $45(28.1)$ & $56(45.9)$ & $135(31.8)$ \\
\hline Type S (unambitious) & $20(14.1)$ & $34(21.3)$ & $27(22.1)$ & $81(19.1)$ \\
\hline Risk Type A (excessively ambitious) & $45(31.7)$ & $35(21.9)$ & $22(18)$ & $102(24.1)$ \\
\hline Type B (burnout) & $43(30.3)$ & $46(28.8)$ & $17(13.9)$ & $106(25)$ \\
\hline Total & $142(100)$ & $160(100)$ & $122(100)$ & $424(100)$ \\
\hline chi $^{2}$ test, $p$ & $27.951,<0.001$ & & \\
\hline
\end{tabular}

$\mathrm{Chi}^{2}$ test - Pearson's test of independence; $p$ - level of significance.

\begin{tabular}{|c|c|c|c|c|c|c|c|c|}
\hline Variable & Types o & lated behavior & Total & $\mathrm{H} ; \mathrm{p}$ & Physicians & Nurses & Paramedics & $\mathrm{H} ; \boldsymbol{p}$ \\
\hline \multirow[t]{4}{*}{ Age } & Type G & $\begin{array}{l}M \\
Q_{1}-Q_{3}\end{array}$ & \begin{tabular}{|l}
26.5 \\
$23.3-39.8$ \\
\end{tabular} & \multirow[t]{4}{*}{$\begin{array}{l}5.36 \\
0.15\end{array}$} & $\begin{array}{l}27.5 \\
25-29\end{array}$ & \begin{tabular}{|l|}
39 \\
$22.25-44$
\end{tabular} & $\begin{array}{l}25 \\
23-34\end{array}$ & \begin{tabular}{|l|}
6.30 \\
0.43 \\
\end{tabular} \\
\hline & Type S & $\begin{array}{l}M \\
Q_{1}-Q_{3}\end{array}$ & \begin{tabular}{|l|}
28 \\
$24-41$ \\
\end{tabular} & & $\begin{array}{l}27.5 \\
25-34.5\end{array}$ & \begin{tabular}{|l|}
39 \\
$22.25-48$ \\
\end{tabular} & $\begin{array}{l}25.5 \\
23.5-35.3\end{array}$ & \begin{tabular}{|l|}
3.58 \\
0.17 \\
\end{tabular} \\
\hline & Type A & $\begin{array}{l}M \\
Q_{1}-Q_{3}\end{array}$ & \begin{tabular}{|l}
30 \\
$25-45$ \\
\end{tabular} & & $\begin{array}{l}28.5 \\
25-42\end{array}$ & \begin{tabular}{|l}
41 \\
$27.25-50$ \\
\end{tabular} & $\begin{array}{l}26 \\
23.5-36.5\end{array}$ & $\begin{array}{l}8.89 \\
0.01 \\
\end{array}$ \\
\hline & Type B & $\begin{array}{l}M \\
Q_{1}-Q_{3}\end{array}$ & \begin{tabular}{|l}
29 \\
$24-45$
\end{tabular} & & $\begin{array}{l}27 \\
25-41\end{array}$ & \begin{tabular}{|l}
39 \\
$23-46.25$
\end{tabular} & $\begin{array}{l}33 \\
22.5-41\end{array}$ & $\begin{array}{l}0.51 \\
0.78\end{array}$ \\
\hline
\end{tabular}




\begin{tabular}{|c|c|c|c|c|c|c|c|c|}
\hline Variable & Types of wo & lated behavior & Total & $H ; p$ & Physicians & Nurses & Paramedics & $\mathrm{H} ; \mathrm{p}$ \\
\hline \multirow[t]{4}{*}{ Years in the profession } & Type G & $\begin{array}{l}M \\
Q_{1}-Q_{3}\end{array}$ & \begin{tabular}{|l|}
10 \\
$2-22.5$ \\
\end{tabular} & \multirow[t]{4}{*}{$\begin{array}{l}5.69 \\
0.13\end{array}$} & $\begin{array}{l}2.5 \\
1.25-17.75\end{array}$ & \begin{tabular}{|l|}
21 \\
$11.5-30$ \\
\end{tabular} & \begin{tabular}{|l}
7 \\
$2-15$ \\
\end{tabular} & $\begin{array}{l}15.37 \\
<0.001 \\
\end{array}$ \\
\hline & Type S & $\begin{array}{l} \\
Q_{1}-Q_{3} \\
\end{array}$ & \begin{tabular}{|l|}
15 \\
$4-24.5$ \\
\end{tabular} & & $\begin{array}{l}4 \\
2-11 \\
\end{array}$ & \begin{tabular}{|l|}
21 \\
$18-29.75$ \\
\end{tabular} & \begin{tabular}{|l|}
9.5 \\
$2-17.75$ \\
\end{tabular} & $\begin{array}{l}18.32 \\
<0.001 \\
\end{array}$ \\
\hline & Risk Type A & $\begin{array}{l}M \\
Q_{1}-Q_{3}\end{array}$ & \begin{tabular}{|l|}
12.5 \\
$3-25.5$ \\
\end{tabular} & & $\begin{array}{l}5.5 \\
2.75-16.25\end{array}$ & \begin{tabular}{|l|}
24.5 \\
$15-32$ \\
\end{tabular} & \begin{tabular}{|l|} 
\\
$2-11.75$ \\
\end{tabular} & $\begin{array}{l}17.29 \\
<0.001 \\
\end{array}$ \\
\hline & Type B & $\begin{array}{l}M \\
Q_{1}-Q_{3}\end{array}$ & $\begin{array}{l}19.5 \\
4-25 \\
\end{array}$ & & $\begin{array}{l}4.5 \\
2-30\end{array}$ & \begin{tabular}{|l}
20.5 \\
$16.75-25$ \\
\end{tabular} & \begin{tabular}{|l|}
13.5 \\
$4.75-41$ \\
\end{tabular} & $\begin{array}{l}4.37 \\
0.112 \\
\end{array}$ \\
\hline \multirow[t]{4}{*}{$\begin{array}{l}\text { Years in the previous } \\
\text { job }\end{array}$} & Type G & $\begin{array}{l}M \\
Q_{1}-Q_{3}\end{array}$ & \begin{tabular}{|l} 
\\
$1-16.5$ \\
\end{tabular} & \multirow[t]{4}{*}{$\begin{array}{l}4.74 \\
0.19\end{array}$} & $\begin{array}{l}1.5 \\
1-4.5 \\
\end{array}$ & $\begin{array}{l}10.5 \\
3-30 \\
\end{array}$ & \begin{tabular}{|l}
4 \\
$1-12$ \\
\end{tabular} & \begin{tabular}{|l|}
12.99 \\
0.002 \\
\end{tabular} \\
\hline & Type S & $\begin{array}{l} \\
Q_{1}-Q_{3} \\
\end{array}$ & \begin{tabular}{|l|}
8 \\
$2-15$ \\
\end{tabular} & & $\begin{array}{l}3 \\
1-4 \\
\end{array}$ & $\begin{array}{l}11.5 \\
5.45-18.8 \\
\end{array}$ & \begin{tabular}{|l|}
7 \\
$2-10.5$ \\
\end{tabular} & $\begin{array}{l}10.42 \\
0.005 \\
\end{array}$ \\
\hline & Type A & $\begin{array}{l}\mathrm{M} \\
\mathrm{Q}_{1}-\mathrm{Q}_{3} \\
\end{array}$ & \begin{tabular}{|l|}
9 \\
$2-20$ \\
\end{tabular} & & $\begin{array}{l}5 \\
2.5-12.5 \\
\end{array}$ & \begin{tabular}{|l|}
15.5 \\
$9-27.75$ \\
\end{tabular} & \begin{tabular}{|l|}
2 \\
$1-10.25$ \\
\end{tabular} & $\begin{array}{l}14.45 \\
0.001 \\
\end{array}$ \\
\hline & Type B & $\begin{array}{l}M \\
Q_{1}-Q_{3}\end{array}$ & $\begin{array}{l}10.5 \\
2-20\end{array}$ & & $\begin{array}{l}2.5 \\
1-11.25\end{array}$ & $\begin{array}{l}16 \\
5.75-20.25\end{array}$ & \begin{tabular}{|l}
10.5 \\
$2.5-19.3$ \\
\end{tabular} & $\begin{array}{l}10.42 \\
0.005 \\
\end{array}$ \\
\hline
\end{tabular}

$\mathrm{H}$ - Kruskal-Wallis test value; $\mathrm{M}-$ mean; $\mathrm{Q}_{1}-\mathrm{Q}_{3}-$ first quartile - third quartile.

\begin{tabular}{|c|c|c|c|c|c|c|c|c|c|c|c|c|}
\hline \multirow{2}{*}{$\begin{array}{l}\text { The SCQ } \\
\text { competence } \\
\text { scales }\end{array}$} & \multicolumn{4}{|l|}{ Sten scores } & \multicolumn{3}{|c|}{$\begin{array}{l}\text { Competence levels } \\
\text { - sten scores - } n(\%)\end{array}$} & $\begin{array}{l}\mathrm{Ph} \\
(1)\end{array}$ & $\begin{array}{l}\mathrm{Nu} \\
(2)\end{array}$ & $\begin{array}{l}\mathrm{Pm} \\
(3)\end{array}$ & \multirow[t]{2}{*}{$F$} & \multirow{2}{*}{ 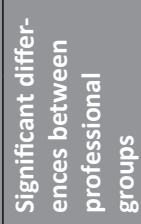 } \\
\hline & $\mathrm{M} \pm \mathrm{SD}$ & Me & $\left|\begin{array}{l}\min \cdot- \\
-\max .\end{array}\right|$ & $Q_{1}-Q_{3}$ & $\begin{array}{l}1-3 \\
\text { low }\end{array}$ & $\mid \begin{array}{l}4-7 \\
\text { average }\end{array}$ & $\begin{array}{l}8-10 \\
\text { high }\end{array}$ & \multicolumn{3}{|l|}{$\mathrm{M} \pm \mathrm{SD}$} & & \\
\hline I sten & $6.14 \pm 2.5$ & 6 & $1-10$ & $4-8$ & 65 (15.1) & 236 (54.6) & $131(30.3)$ & $5.62 \pm 2.37$ & $6.84 \pm 2.67$ & $5.81 \pm 2.19$ & $\begin{array}{l}11.09 \\
<0.001\end{array}$ & $\begin{array}{l}1-2 \\
2-3\end{array}$ \\
\hline SE sten & $5.81 \pm 2.26$ & 6 & $1-10$ & $4-7$ & 68 (15.7) & $267(61.8)$ & $97(22.5)$ & $5.81 \pm 2.14$ & $5.55 \pm 2.33$ & $6.19 \pm 2.27$ & $\begin{array}{l}2.87 \\
0.06\end{array}$ & $2-3$ \\
\hline A sten & $5.92 \pm 2.34$ & 5 & $1-10$ & $4-8$ & 61 (14.1) & $261(60.4)$ & $110(25.5)$ & $5.00 \pm 2.05$ & $6.39 \pm 2.64$ & $6.37 \pm 1.89$ & \begin{tabular}{|l|}
18.12 \\
$<0.001$ \\
\end{tabular} & $\begin{array}{l}1-2 \\
1-3 \\
\end{array}$ \\
\hline SCQ sten & $5.73 \pm 2.24$ & 6 & $1-10$ & $4-7$ & $66(15.3)$ & $271(62.7)$ & $95(22)$ & $5.39 \pm 2.19$ & $5.80 \pm 2.25$ & $6.05 \pm 2.24$ & $\begin{array}{l}3.03 \\
0.05\end{array}$ & $1-3$ \\
\hline
\end{tabular}

M - mean; SD - standard deviation; Me - median; $p$ - level of significance for F; Ph - physicians; Nu - nurses; Pm - paramedics; F - ANOVA with Tukey's post hoc test. Scales of competence determining the effectiveness of behavior in I - intimate situations; SE - social exposure situations; A - situations requiring assertiveness; SCQ - social competence questionaire.

from physicians, and physicians from paramedics ( $F=11.09$; $p<0.001$ ). Competence in social exposure situations (SE) - which refers to being an object of attention and potential appraisal - differs paramedics from nurses $(\mathrm{F}=2.87 ; p=0.06)$.

\section{Statistically significant correlations}

Analysis of stanine scores for behavior types (AVEM) and sten scores for social competence (SCQ) revealed a statistically significant correlation between Type $\mathrm{G}$ (healthy-ambitious) behavior and the general social competence level $(r=0.17 ; p=$ $0.05)$, as well as a negative correlation between Type B (burnout) behavior and the I scale $(r=-0.23 ; p=0.02)$.

There were significant differences in work-related behaviors and experiences between the professional groups analyzed in our study. The greatest differences between physicians, nurses and paramedics were observed in resistance to stress (6-8), commitment to work (2-3 and 5) and emotional or subjective well-being (10) (Table 5).

\begin{tabular}{|c|c|c|c|c|c|c|}
\hline \multicolumn{3}{|c|}{ Types of work-related behaviors } & \multirow{2}{*}{\begin{tabular}{|l|}
$\begin{array}{l}\text { Physicians } \\
\mathrm{M} \pm \text { SD }\end{array}$ \\
$16.13 \pm 5.02$
\end{tabular}} & \multirow{2}{*}{$\begin{array}{l}\text { Nurses } \\
M \pm \text { SD } \\
16.14 \pm 4.67\end{array}$} & \multirow{2}{*}{$\begin{array}{l}\text { Paramedics } \\
\mathrm{M} \pm \mathrm{SD} \\
16.25 \pm 4.47\end{array}$} & \multirow{2}{*}{\begin{tabular}{|l|}
$\mathrm{F}$ \\
$p$ \\
0.03 \\
0.98 \\
\end{tabular}} \\
\hline \multirow{5}{*}{ 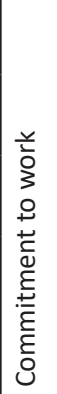 } & 1 & perceived significance of work & & & & \\
\hline & 2 & career ambition & $22.08 \pm 3.92$ & $20.28 \pm 4.02$ & $21.12 \pm 3.92$ & $\begin{array}{l}7.74 \\
0.001 \\
\end{array}$ \\
\hline & 3 & tendency to exert & $20.43 \pm 4.16$ & $19.80 \pm 4.49$ & $21.06 \pm 4.09$ & $\begin{array}{l}3.02 \\
0.05\end{array}$ \\
\hline & 4 & striving for perfection & $22.77 \pm 4.15$ & $22.54 \pm 4.21$ & $23.20 \pm 3.67$ & $\begin{array}{l}0.91 \\
0.40\end{array}$ \\
\hline & 5 & emotional distancing & $17.93 \pm 4.75$ & $20.05 \pm 4.43$ & $21.08 \pm 3.95$ & $\begin{array}{l}17.91 \\
0.001\end{array}$ \\
\hline
\end{tabular}




\begin{tabular}{|c|c|c|c|c|c|c|}
\hline \multicolumn{3}{|c|}{ Types of work-related behaviors } & \multirow{2}{*}{\begin{tabular}{|l|}
$\begin{array}{l}\text { Physicians } \\
\mathrm{M} \pm \text { SD }\end{array}$ \\
$17.54 \pm 4.43$
\end{tabular}} & \multirow{2}{*}{$\begin{array}{l}\text { Nurses } \\
M \pm S D \\
15.66 \pm 4.28\end{array}$} & \multirow{2}{*}{$\begin{array}{l}\text { Paramedics } \\
M \pm \text { SD } \\
14.51 \pm 4.44\end{array}$} & \multirow{2}{*}{\begin{tabular}{|l|}
$F$ \\
$p$ \\
16.28 \\
0.001 \\
\end{tabular}} \\
\hline \multirow{3}{*}{ 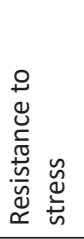 } & 6 & tendency to resignation & & & & \\
\hline & 7 & active coping with problems & $20.80 \pm 3.94$ & $21.84 \pm 3.75$ & $23.14 \pm 4.09$ & $\begin{array}{l}11.78 \\
0.001\end{array}$ \\
\hline & 8 & balance and emotional stability & $19.49 \pm 4.29$ & $19.69 \pm 3.93$ & $21.80 \pm 4.12$ & $\begin{array}{l}12.55 \\
0.001 \\
\end{array}$ \\
\hline \multirow{3}{*}{ 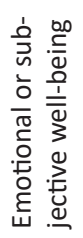 } & 9 & work satisfaction & $20.25 \pm 4.41$ & $19.81 \pm 3.64$ & $20.80 \pm 3.80$ & $\begin{array}{l}2.13 \\
0.12 \\
\end{array}$ \\
\hline & 10 & life satisfaction & $20.97 \pm 4.52$ & $21.03 \pm 4.13$ & $22.15 \pm 4.27$ & $\begin{array}{l}3.09 \\
0.05 \\
\end{array}$ \\
\hline & 11 & perceived social support & $21.74 \pm 4.30$ & $21.34 \pm 3.99$ & $22.28 \pm 3.86$ & $\begin{array}{l}1.83 \\
0.16\end{array}$ \\
\hline
\end{tabular}

F - ANOVA with Tukey's post hoc test; $p$ - level of significance for F.

\section{Discussion}

Our study demonstrated symptoms of work-related behaviors indicating professional burnout (Type B) in one fourth of medical workers irrespective of their workplace. Similar results were obtained by $[1,21,22]$. Physicians and nurses belong to professional groups which present behaviors typical of burnout syndrome (Type B) and excessive ambition (Risk Type A), observed especially in the dimensions of commitment to work and resistance to stress. Risk Type A behaviors were noted in less than one third of physicians, one fifth of nurses and $18 \%$ of paramedics - mainly in the dimension of resistance to stress (tendency to resignation). Similar results were obtained by Voltmer et al. in their large-scale study of physicians $(n=344)$ and nurses ( $n=389$ ), performed using the AVEM questionnaire [34]. The researchers compared work-related behaviors and experiences of the respondents at various stages of their career. They found that the percentage of individuals showing symptoms of burnout syndrome (Type B) was higher among nurses (32.8\%) than among physicians $(27.3 \%)$, and - as in our study - the differences were observed in the dimensions of commitment to work and resistance to stress. Voltmer et al. also reported that $22 \%$ of physicians of different specialties, employed in various medical practices, were excessively ambitious (Risk Type A) [34]. Taking into account the course and causes of the burning-out process, as well as its health, social and economic consequences, such a combination of behavior types (Risk Type A and Type B) is an alarming phenomenon. Aouli and Haj-Bakri noted that as many as $44 \%$ of 100 internists assessed by the AVEM questionnaire suffered from burnout syndrome, $28 \%$ were at a risk of it, and only $6 \%$ exhibited healthy behaviors (Type G) [35]. According to these authors, workers presenting healthy behaviors (Type G) had most probably developed a protective barrier against job burnout. This barrier can be a high social competence level, which helps people to adapt to difficult working conditions [35].

Type S (unambitious), characterized by reduced work commitment, is observed in more than one fifth of paramedics and nurses and in only $14 \%$ of physicians, manifesting mainly as the ability to keep an emotional distance. This type of work-related behavior is very desirable in medical professions, which involve a substantial psychological burden and the necessity of making quick decisions. Type $\mathrm{S}$ behaviors allow workers to act with due caution when making decisions and to reduce their mental effort [21].

In our study, nurses presenting healthy behaviors (Type G) were more numerous (28.1\%) than physicians (23.9\%), but less numerous than paramedics (45.9\%). These behaviors are characterized by high career ambition combined with moderate perceived significance of work and moderate tendency to exert, as well as a low tendency to resign, active coping with problems, balance and emotional stability.

Burnout syndrome affects younger and younger people with fewer years in the profession. What is worrying is the fact that physicians suffering from job burnout are younger than nurses and have fewer years of service. Our analysis provides evidence that age, female gender, years in the profession and years in the present job increase the incidence of burnout syndrome, especially among nurses. Intensification of burnout syndrome among females, which our research has indicated, may be the result of the overrepresentation of the share of females in the study. This is the result of feminization of healthcare professions in Poland. The lowest share of females was in the group of paramedics, and the highest was in the group of nurses. Similar results in the distribution of females in groups of physicians and students of medicine were also observed in the study by Mroczek et al. [8].

Similar results regarding the correlation of age, gender and number of years in the profession among paramedics were obtained by Szaton et al. [22]. They also confirmed a higher intensity of professional burnout among females [22]. The mean age of the nurses in our study and all nurses in Poland ( 49 years in 2016) implies that this group of healthcare workers is at the highest risk of burnout (especially nurses employed in primary, palliative and long-term care) $[36,37]$. Our research revealed that the number of years in the present workplace contributes to job burnout among nurses. Ross et al. reported a similar relationship, indicating that working for many years in one place creates favorable conditions for developing a feeling of overexertion and burnout syndrome [38]. Third-level education is a factor that promotes healthy work-related behaviors, distancing one from health problems, Type $S$ (unambitious) behaviors and greater professional ambitions. The study of 63 primary care physicians conducted by Sapilak et al. demonstrated fullblown burnout syndrome in $29 \%$ (18) of the participants. It provided also evidence for a positive correlation between job burnout and the number of workplaces [5].

These results correspond with social competence levels. In our study sample, over three fourths of the medical workers had average and low competence levels, and only every fifth person had a high competence level. Differences in the levels of I and A competence between the professional groups were significant. Nurses had higher competence in intimate situations (I) than physicians and paramedics. Physicians had a lower level of competence in situations demanding assertiveness (A) than nurses and paramedics. Lower I competence was accompanied by burnout syndrome (Type B). Pereira-Lima and Loureiro analyzed the connection between social competence, burnout syndrome and mental health problems in a group of 400 medical residents in Brasil [12]. They found a statistically significant 
relationship between a high social competence level and the lack of anxiety, depression and burnout symptoms measured by the Burnout Syndrome Inventory (BSI). Similarly, those with lower competence levels were more likely to develop burnout syndrome, anxiety and depression.

\section{Limitations of the study}

The sample size of 432 health workers may not have been adequate to power the study to allow for generalization of the findings to a national level. The study project was developed based on the assumption that research is going to be conducted only among physicians, nurses and paramedics due to nature of interpersonal relationships in the therapeutic team and the variability of work places in healthcare.

Another limitation is the fact that the data was gathered via self-reports. However, the study was prospective, which diminishes the risk for problems related to common method bias.

\section{Conclusions}

Burnout syndrome (Type B) occurs in physicians, nurses and paramedics regardless of their place of work and is related to a low level of social competence, particularly in intimate situations. Selected variables differentiate the occurrence of types of professional burnout between groups of professionals. Low social competence results in paramedics being more inclined to give up when facing failure.

The results obtained in our study clearly show that the problem of job burnout in medical professions is vital and requires immediate therapeutic and preventive solutions. It is important to supplement a diagnosis of work-related behavior types with an analysis of external learning and working conditions. Prevention programs should enhance the social competence of healthcare professionals.

Source of funding: This work was funded by the authors' own resources.

Conflict of interest: The authors declare no conflict of interests.

\section{References}

1. Schaarschmidt U, Fischer AW. AVEM - ein diagnostisches Instrument zur Differenzierung von Typen gesundheitsrelevanten Verhaltens und Erlebens gegenüber der Arbeit. Zeitschrift für Differentielle und Diagnostische. Psychologie 1997; 18(3): 151-163 (in German).

2. Wilczek-Różyczka E. Wypalenie zawodowe pracowników medycznych. Warszawa: Wydawnictwo ABC Wolters Kluwer; 2014: 76-78 (in Polish).

3. Freudenberger HJ. Staff burn-out. J Soc Issues 1974; 30(1): 159-165, doi: 10.1111/j.1540-4560.1974.tb00706.x.

4. Kalimo R, Pahkin K, Mutanen $\mathrm{P}$, et al. Staying well or burning out at work: work characteristics and personal resources as long-term predictors. Work Stress 2003; 17(2): 109-122.

5. Sapilak BJ, Kurpas D, Steciwko A, et al. Wypalenie zawodowe personelu medycznego - problem wciąż aktualny. Metody oceny i przeciwdziałania w ramach oddziałów dializacyjnych. Probl Lek 2006; 45(3): 81-83 (in Polish).

6. Fink E. Sich einsetzen ohne auszubrennen. Burnoutpravention in der Sozialen Arbeit. 2011. Available from URL: https://hses.bszbw.de/ files/119/Sich_einsetzen_ohne_auszubrennen.pdf (in German).

7. Cañadas-De la Fuente GA, Vargas C, San Luis C, et al. Risk factors of burnout syndrome in the nursing profession. Int J Nurs Stud 2015; 52(1): 240-249.

8. Mroczek B, Zarek A, Rudnicki J, et al. Social competence of physicians and medical students - a preliminary report. Fam Med Prim Care Rev 2016; 18(3): 308-312, doi: https://doi.org/10.5114/fmpcr/62754.

9. Leiter MP. Coping patterns as predictors of burnout. J Organ Behav 1991; 12(2): 123-144, doi: 10.1002/job.4030120205.

10. Maslach C. Job burnout: new directions in research and intervention. Current Directions Psychol Sci 2003; 12(5): 189-192.

11. Dyrbye L, Shanafeld T. A narrative review on burnout experienced by medical students and residents. Med Educ 2016; 50(1): 132-149, doi: 10.1111/medu.12927.

12. Pereira-Lima K, Loureiro SR. Burnout, anxiety, depression, and social skills in medical residents. Psychol Health Med 2015; 20(3): 353-362, doi: 10.1080/13548506.2014.936889.

13. Saulsman LM, Page AC. The five-factor model and personality disorder empirical literature: a meta-analytic review. Psychol Rev 2014; 23(8): 1055-1085.

14. Armon G, Melamed S, Shirom A, et al. Elevated burnout predicts the onset of musculoskeletal pain among apparently healthy employees. J Occup Health Psych 2010; 15(4): 399-408.

15. Malouff JM, Thorsteinsson EB, Schutte NS. The relatiosnship between the five-factor model of personality and symptoms of clinical disorders: a meta-analysis. J Psychopathol Behav 2005; 27(2): 101-114, doi: 10.1007/s10862-005-5384-y.

16. Brayer A, Foley M, Doroszkiewicz A, et al. Job satisfaction among masters in nursing in Central and East Poland: a preliminary study. Fam Med Prim Care Rev 2017; 19(1): 7-11, doi: 10.5114/fmpcr/62754.

17. Năstasă LE, Fărcaş AD. The effect of emotional intelligence on burnout in healthcare professionals. Procedia - Social and Behavioral Sciences 2015; 187: 78-82.

18. Ahola K, Väänänen A, Koskinen A, et al. Burnout as a predictor of all-cause mortality among industrial employees: a 10-year prospective register-linkage study. J Psychosom Res 2010; 69(1): 51-57.

19. Narumoto J, Nakamura K, Kitabayashi Y. Relationships among burnout, coping style and personality: study of Japanese professional caregivers for elderly. Psychiatry Clin Neurosci 2008; 62(2): 174-176.

20. Wilczek-Rużyczka E, Plewa Z. Wypalenie zawodowe u pracowników ochrony zdrowia. Med Rodz 2008; 3: 69-71 (in Polish).

21. Schaarschmidt U. AVEM - ein personlichkeitsdiagnostisches Instrument für die berufsbezogene rehabilitation. Bonn: Deutscher Psychologen Verlag GmbH; 2006: 59-82 (in German).

22. Szaton M, Harazin B. Wypalenie zawodowe w wybranych zespołach ratownictwa medycznego w województwie śląskim. Ann Acad Med Siles 2013; 67(1): 28-32 (in Polish).

23. Siemiński M, Nitka-Siemińska A, Nyka WM. Zespół wypalenia. Forum Med Rodz 2007; 1(1): 45-49 (in Polish).

24. Riggio RE, Taylor SJ. Personality and communication skills as predictors of hospice nurse performance. J Bus Psychol 2000; 15(2): 251-359.

25. Kuokkanen L, Leino-Kilpi H. The qualities of an empowered nurse and the factors involved. J Nurs Manag 2001; 9(5): $273-280$.

26. Okuyama A, Wagner C, Bijnen B. How we can enhance nurses' assertiveness: a literature review. J Nurs Care 2014; 3: 194, doi: 10.4172/2167-1168.1000194. 
27. Rongińska T, Gaida WA. Strategie radzenia sobie z obciqżeniem psychicznym w pracy zawodowej. Zielona Góra: Oficyna Wydawnicza Uniwersytetu Zielonogórskiego; 2012 (in Polish).

28. Tomorowicz A. The structure of social skills in interactive embrace. Psychiatry 2011; 8(3): 91-96.

29. Martowska K. Temperamental determinants of social competencies. Pol Psychol Bull 2014; 45(2): 128-133, doi: 10.2478/ppb-20140017.

30. Kapała W. Organizacja pracy a jakość usług medycznych. Antidotum 2001; 4: 17 (in Polish).

31. Orzechowska A, Talarowska M, Drozda R, et al. Zespół wypalenia zawodowego u lekarzy i pielęgniarek. Pol Merkuriusz Lek 2008; 25(150): 507-509 (in Polish).

32. Matczak A. Kwestionariusz Kompetencji Społecznych. Warszawa: Pracownia Testów Psychologicznych; 2007 (in Polish).

33. Argyle M. The psychology of interpersonal behaviors. 5th ed. London: Penguin Books; 1994.

34. Voltmer E, Schwappach DLB, Frank E, et al. Work-related behavior and experience patterns and predictors of mental health in German physicians in medical practice. Fam Med 2010; 42(6): 433-439.

35. Aouli B, Haj-Bakri B. Wypalenie zawodowe a poczucie sensu życia lekarzy internistów. Psychologia.net.pl 2006 [cited 6.02.2017]. Available from URL: http://www.psychologia.net.pl/artykul.php?level=201 (in Polish).

36. Haor B, Głowacka M, Ślusarz R, et al. Zachowania i przeżycia pielęgniarek związane z pracą zawodową. Probl Pielęg 2014; 22(2): 142-146. (in Polish).

37. Wieder-Huszla S, Żak B, Jurczak A, et al. Occupational burnout among nursing personnel. Fam Med Prim Care Rev 2016; 18(1): 63-68.

38. Ross J, Jones J, Callaghan P, et al. A survey of stress, job satisfaction and burnout among haemodialysis staff. J Renal Care 2009; 35(3): 127-133.

Tables: 5

Figures: 0

References: 38

Received: 17.06.2017

Reviewed: 28.06.2017

Accepted: 27.07.2017

Address for correspondence:

Iwona Karpeta-Pawlak, MA

Zakład Nauk Humanistycznych w Medycynie PUM

ul. gen. Dezyderego Chłapowskiego 11

70-103 Szczecin

Polska

Tel.: +48 514 371-596

E-mail: iwona.pawlak@pum.edu.pl 